\title{
Nicotine dependence and levels of depression and anxiety in smokers in the process of smoking cessation
}

\author{
Dependência nicotínica e níveis de depressão e ansiedade em fumantes em processo de cessação \\ Maritza Muzzi Cardozo Pawlina1, Regina de Cássia Rondina², Mariano Martinez Espinosa³, Clóvis Botelho ${ }^{3}$ \\ ' State Department of Health of Mato Grosso (SES/MT) and Federal University of Mato Grosso (UFMT), Cuiabá, MT, Brazil. \\ 2 São Paulo State University, São Paulo, SP, Brazil. \\ ${ }_{3}^{3}$ Federal University of Mato Grosso (UFMT), Cuiabá, MT, Brazil.
}

Received: 12/19/2013 - Accepted: 6/27/2014

DOI: 10.1590/0101-60830000000020

\begin{abstract}
Background: Depression and anxiety are psychiatric disorders that are related to tobacco use and associated with dependence, the process of cessation, lapses and relapses after quitting smoking. Objective: To analyze the association of nicotine dependence with the level of anxiety and depression in patients who are in the process of smoking cessation. Methods: Cross-sectional study conducted with patients who sought the smoking cessation program in Cuiabá/MT. All the smokers enrolled from May to August 2012, participated in this study. Four instruments were applied: Socio-demographic Questionnaire, Fagerström test, Beck Anxiety Inventory and Beck Depression Inventory. Following bivariate analysis, using the crude prevalence ratio, with level of significance lower than $5 \%(\mathrm{p}<0.05)$, having as variable outcome the nicotine dependence $\geq 5$ (Fagerström). The associations with $\mathrm{p}<0.20$ were selected for robust Multiple Poisson Regression $\left(\mathrm{RP}_{\mathrm{a}}\right)$. Results: Associations of Fagerström $\geq 5$ with the male sex $(\mathrm{RP}=1.15 \mathrm{CI} 95 \% 1.03-1.28)$; number of cigarettes/day $(\mathrm{RP}=1,33$; $\mathrm{CI}$ $95 \%$ 1.19-1.48); and moderate/severe level of depression ( $\mathrm{RP}=1.15$; CI 95\% 1.04-1.28) were found. In the final model (RPa), the following variables remained associated: male gender (RPa 1.12; CI 95\% 1.01-1.24), number of cigarettes/day (RPa 1.28; CI 95\% 1.15-1.43) and high level of depression (RPa 1.12; CI 95\% 1.01-1.23). Discussion: High level of nicotine dependence was associated significantly with the level of depression, emphasizing the association between smoking and psychiatric comorbidities.
\end{abstract}

Pawlina MMC, et al. / Rev Psiq Clín. 2014;41(4):101-5

Keywords: Smoking, Fagerström, nicotine dependence, anxiety, depression.

\section{Resumo}

Contexto: Depressão e ansiedade são patologias psiquiátricas que estão relacionadas ao tabagismo e associadas com a dependência, o processo de cessação, lapsos e recaídas após parar de fumar. Objetivo: Analisar a associação da dependência da nicotina com o nível de ansiedade e depressão de pacientes em cessação do tabagismo. Métodos: Estudo transversal realizado com pacientes dos programas de cessação do tabagismo de Cuiabá/MT. Todos os fumantes matriculados, durante o período de maio a agosto de 2012, participaram deste estudo. Foram aplicados quatro instrumentos: Questionário sociodemográfico, teste de Fagerström, Inventário de Ansiedade de Beck e Inventário de Depressão de Beck. Feita análise bivariada, razão de prevalência bruta, com nível de significância de $5 \%(\mathrm{p}<0,05)$, tendo como variável desfecho a dependência nicotínica $\geq$ a 5 (Fagerström). As associações com $\mathrm{p}<0,20$ foram selecionadas para a Regressão de Poisson Múltipla robusta $\left(\mathrm{RP}_{\mathrm{a}}\right)$. Resultados: Foram encontradas associações do Fagerström $\geq 5$ com sexo masculino $(\mathrm{RP}=1,15 \mathrm{IC} 95 \%$ 1,03-1,28); quantidade de cigarros fumados/dia ( $\mathrm{RP}=1,33$; IC 95\% 1,19-1,48); e nível de depressão moderado/grave ( $\mathrm{RP}=1,15$; IC 95\% 1,04-1,28). No modelo final (RPa), permaneceram associadas as variáveis: sexo masculino (RPa 1,12; IC 95\% 1,01-1,24), número de cigarros/dia (RPa 1,28; IC 95\% 1,15-1,43) e alto nível de depressão (RPa 1,12; IC 95\% 1,01-1,23). Conclusão: Alta dependência de nicotina foi associada significativamente ao nível de depressão, evidenciando a associação entre tabagismo e comorbidades psiquiátricas.

Pawlina MMC, et al. / Rev Psiq Clín. 2014;41(4):101-5

Palavras-chave: Tabagismo, Fagerström, dependência nicotínica, ansiedade, depressão.

\section{Introduction}

Smoking, besides being a known risk factor for several diseases, is itself a disease. Mostly, the beginning of this disease is explained by nicotine dependence that most of the smokers have, being related to the genetics of the individual, environmental factors and the number of cigarettes smoked/time spent smoking (smoking burden)1,2. The clinical expression of this dependence occurs when the smoker quits smoking and presents a large variety of characteristic symptoms (craving, tremors, sweating, agitation, lack of concentration etc.), emphasizing the intense desire to smoke again, which most of the time becomes compulsive and uncontrollable (craving) ${ }^{2,3}$.

The evaluation of the nicotine dependence becomes indispensable for the smokers in the cessation process, because among the factors that make this process even more difficult, the degree of dependence is determinant, both in the decision-making to quit the cigarette and to continue without it $2,4,5$. The Fagerströn Test is the most known evaluation tool and when the smoker reaches five or more points in this test he/she is classified as being on a medium, high or very high dependence level. The smoker being considered as a heavy smoker has the biggest chances of failure ${ }^{3}$. Moreover, there is a need for medication due to the degree of physical dependence on nicotine, which demands drug intervention and/or the behavioral cognitive therapy (BCT), in order to ensure less individual suffering and improve the chances of success. The remission rate without intervention is very high in this kind of smoker ${ }^{2,3}$.

The relation between depression and anxiety with smoking has been reported in literature, with these variables associated both with the addiction itself, regarding the limiting factors in the cessation process, as well as facilitators of lapses and relapses after quitting smoking with or without pharmacological treatment or psychological support with the TCC6.

Concerning depression, there are several hypotheses about the nature of this association. Smoking could act as "self-medication" of feelings of sadness or negative mood. There is evidence that the use of nicotine interferes with the neurochemical systems and fosters 
the neural circuits of the central nervous system, such as reinforcement mechanisms associated with mood regulator ${ }^{7}$. There is also the hypothesis that, more than a unidirectional relation, smoking and depression can influence each other reciprocally. Depressed smokers can smoke to alleviate their negative feelings and, therefore, smoking for these individuals becomes reinforcing. Another explanatory theory that has been gaining more adepts is that a series of common variables (such as genetic and psychosocial factors), contribute for the expression of both (smoking and depression) 8 . In the smokers with depressive symptoms in the cessation process, it is known that the probability of smoking abandonment is reduced, with higher risk of relapse during the withdrawal period, compared to the smoker without the same history ${ }^{2}$. Furthermore, this smoker runs the risk of developing more significant depressive episodes, often requiring specific treatment or even specialized help in the treatment of psychiatric diseases 9 .

In relation to anxiety, it is known that anxious people are more likely to start smoking and also to become tobacco dependent ${ }^{10}$. To some extent, this is explained by the effect of nicotine in the brain circuits when anxiety is reduced, euphoria is produced and other sensations perceived as pleasant by the smoker ${ }^{11}$. Mood changes are noticed when the smoker is in the withdrawal process, because that apparent balance is lost, turning him into an agitated, impatient and lacking the necessary concentration for his daily activities ${ }^{12}$. Thus, smokers diagnosed with anxiety tend to have lower probabilities of withdrawal in the long term, compared to those without diagnoses of anxiety, who need to be monitored throughout the cessation process $^{13}$.

This study has been designed taking into account the knowledge about the relation between smoking and psychological and/ or psychiatric disorders in smokers in the process of cessation. The main aim is to analyze the relation between the nicotine dependence level and the levels of depression and anxiety, aiming to support and optimize the action planning of the cessation programs.

\section{Methods}

This is a descriptive and cross-sectional study with evaluation of 216 patients enrolled in the Tobacco Control Program within the public sector from May to August 2012. These patients were from the four Health Units of Cuiabá/MT-Brazil (Júlio Müller University Hospital, Coxipó Polyclinic, Planalto Polyclinic and Campo Velho Health Center), which provided treatment through the Brazilian Health Care System (SUS) to patients with tobacco dependence.

All the smokers enrolled in the program during the period of study were invited to participate in this study. Participants used the same treatment protocol: Nicotine Replacement Therapy (NRT) + bupropion + cognitive behavioral therapy (CBT). After receiving the medication from the assistant physician all smokers went through the initial assessment (T0) with the main researcher (psychologist) who oriented them about the proposed treatment and scheduled the TCC. After clarification of the objective proposed and the signing of the Free and Informed Consent the following tools for data collection were applied:

1. Socio-demographic profile questionnaire: Prepared by researchers for this study and divided into two parts. Part I - Identification and socio-demographic data: gender, age, school level, marital status, income and occupation/ profession. Part II - Smoking status: how long he/she has been smoking, number of cigarettes/day, age at which the person started to smoke and smoking burden (cutoff point 20 years-package). In the results of smoking status, the parameters used to categorize the variables were the median, except in the smoking burden where it was considered a higher dependence for being above $20^{14}$.

2. Fagerström Test (FTND): Self-administered questionnaire which contains 6 items and that shows the individual's degree of dependence in relation to nicotine in the levels: very low ( 0 to 2 points), low ( 3 to 4 points), moderate ( 5 points), high
(6 to 7 points) and very high ( 8 to 10 points) ${ }^{15}$. For statistical analysis of the results, the smokers with results $\geq 5$ were classified as highly dependent and the value below 5 as mildly dependent 3,14 .

3. Beck Anxiety Inventory (BAI): A scale that was developed in order to measure anxiety both in psychiatric patients and in the general population and consists of a list with $21 \mathrm{common}$ symptoms of anxiety, where the patient indicates how he had been feeling in the previous week, up to the current day. For this study the results were classified in minimal/mild and moderate/severe ${ }^{16}$.

4. Beck Depression Inventory (BDI): This inventory also consists of 21 groups of statements, where the patient indicates how he/she had been feeling the preceding week. The evaluation of the BDI classifies the participants within four levels: minimal, which suggests absence of depression, mild, moderate and severe depression. Here the results were classified in minimal/mild and moderate/severe as well ${ }^{17}$.

Later, the data were entered in an Epidata software version 3.1, and analyzed by the Statistical Package for the Social Sciences (SPSS) version 17.0. Next, a bivariate analysis was carried out, using the crude prevalence ratio with its respective intervals of confidence of 95\% (CI 95\%) and level of significance less than 5\% ( $p<0.05)$. The variables with levels of significance inferior to $20 \%(\mathrm{p}<0.20)$, by the chi-square test, were listed to be tested in the Multiple Poisson Regression Model with strong variance $\left(\mathrm{RP}_{\mathrm{a}}\right)$, remaining in the final model the variables which presented a $\mathrm{p}$ value lower than $5 \%(\mathrm{p}<$ 0.05 ). Poisson model was chosen for being the alternative used in the epidemiological literature which estimates the relative risk in a cross-sectional study, using the prevalence ratio ${ }^{18}$.

The dependent variable (outcome) corresponded to the FTND $\geq 5$. The independent variables were based on three hierarchical levels for determining the variables related to the outcomes which are proximal (anxiety and depression, smoking history and cigarettes per day). Variables representing status of smoking as age of onset, attempts to quit smoking, length of smoking and gender can be considered intermediate. The more distal factors refer to other socio-demographic data such as income, occupation, age and years at school.

This research, with Certificate of Submission for Ethical Review (CAAE $n^{\circ} 0106612.6 .0000 .5541$ ), was approved on May 9th 2012 by the Research Ethics Committee (CEP) of Júlio Müller University Hospital under CEP's Approval nº 19548.

\section{Results}

Table 1 shows the association between the level of nicotine dependence and the socio-demographic factors. It is possible to observe that high nicotine dependence (Fagerström $\geq 5$ ) is associated with the male gender (RP 1.15; CI 95\% 1.03-1.28). There was no association with the other factors studied: age group $(\mathrm{p}=0.615)$, income $(\mathrm{p}=$ $0.892)$, education $(p=0.976)$ and occupation $(p=0.923)$.

The association between the level of nicotine dependence and the smoking status is in table 2. High nicotine dependence is associated with the highest number of cigarettes smoked per day (RP 1.33; CI 95\% 1.19-1.48) and tobacco intake $\geq 20$ (RP 1.35; CI 95\% 1.11-1.64). There was no association between high dependence and length of smoking habit $(\mathrm{p}=0.315)$, age at which he/she started smoking $(\mathrm{p}=$ $0.829)$ or number of attempts to quit smoking $(\mathrm{p}=0.564)$.

The results of the instruments used to evaluate the level of anxiety (BAI) or depression (BDI) are in table 3. It is worth noting that high nicotine dependence is associated with the highest level of depression (RP 1.15; CI 95\% 1.04-1.28), unlike the anxiety level that was not statistically significant $(\mathrm{p}=0.619)$.

In table 4 the final model of the multivariate analysis of the Crude Poisson Regression ( $\mathrm{RPa}$ ) is presented. The following variables remained associated with the high nicotine dependence (Fagerström $\geq 5$ ): male gender ( $\mathrm{RPa} 1.12$; CI 95\% 1.01-1.24), higher number of cigarettes smoked per day (RPa 1.28; CI 95\% 1.15-1.43), and higher level of depression (RPa 1.12; CI 95\% 1.01-1.23). 
Table 1. Results of the bivariate analysis of the association between nicotine dependence and socio-demographic factors, Cuiabá-MT, Brazil

\begin{tabular}{|c|c|c|c|c|c|c|c|c|}
\hline \multirow[t]{3}{*}{ Variables } & \multirow[t]{3}{*}{ Category } & \multicolumn{4}{|c|}{ Fagerström } & \multirow[t]{3}{*}{$\mathrm{RP}_{\mathrm{b}}$} & \multirow[t]{3}{*}{$\mathrm{Cl} 95 \%$} & \multirow[t]{3}{*}{$p$} \\
\hline & & \multicolumn{2}{|c|}{$\geq 5$} & \multicolumn{2}{|c|}{ Until 4} & & & \\
\hline & & $n$ & $\%$ & $\mathrm{n}$ & $\%$ & & & \\
\hline \multirow[t]{2}{*}{ Gender } & Male & 69 & 92.00 & 6 & 8.00 & 1.15 & {$[1.03 ; 1.28]$} & 0.023 \\
\hline & Female & 113 & 80.14 & 28 & 19.86 & 1.00 & - & - \\
\hline \multirow[t]{3}{*}{ Age } & 20-39 years & 41 & 82.00 & 9 & 18.00 & 1.06 & {$[0.84 ; 1.33]$} & 0.615 \\
\hline & 40-59 years & 117 & 86.67 & 18 & 13.33 & 1.12 & {$[0.92 ; 1.37]$} & $0.262 \mathrm{~F}$ \\
\hline & 60 years or more & 24 & 77.42 & 7 & 22.58 & 1.00 & - & - \\
\hline \multirow[t]{2}{*}{ Income } & $>$ Median (2.000) & 78 & 83.87 & 15 & 16.13 & 0.99 & {$[0.88 ; 1.12]$} & 0.892 \\
\hline & $\leq$ Median (2.000) & 104 & 84.55 & 19 & 15.45 & 1.00 & - & - \\
\hline \multirow[t]{2}{*}{ Years of school } & $>8$ & 128 & 84.21 & 24 & 15.79 & 1.00 & {$[0.88 ; 1.13]$} & 0.976 \\
\hline & $\leq 8$ & 54 & 84.38 & 10 & 15.62 & 1.00 & - & - \\
\hline \multirow[t]{2}{*}{ Occupation } & Don't work & 68 & 83.95 & 13 & 16.05 & 0.99 & {$[0.88 ; 1.12]$} & 0.923 \\
\hline & Work & 114 & 84.44 & 21 & 15.56 & 1.00 & - & - \\
\hline
\end{tabular}

$\mathrm{RP}_{\mathrm{b}}$ : Crude Prevalence Ratio; $\mathrm{Cl} 95 \%$ : confidence interval of 95\%; p: Level of significance considering the distribution of the chi-square test.

Table 2. Results of the bivariate analysis of the association between nicotine dependence and smoking status, Cuiabá-MT

\begin{tabular}{|c|c|c|c|c|c|c|c|c|}
\hline \multirow[t]{3}{*}{ Variables } & \multirow[t]{3}{*}{ Categories } & \multicolumn{4}{|c|}{ Fagerström } & \multirow[t]{3}{*}{$\mathrm{RP}_{\mathrm{b}}$} & \multirow[t]{3}{*}{ CI 95\% } & \multirow[t]{3}{*}{$\mathrm{p}$} \\
\hline & & \multicolumn{2}{|c|}{$\geq 5$} & \multicolumn{2}{|c|}{ Until 4} & & & \\
\hline & & $\mathrm{n}$ & $\%$ & $\mathrm{~N}$ & $\%$ & & & \\
\hline \multirow{2}{*}{$\begin{array}{l}\text { Duration of } \\
\text { smoking habit }\end{array}$} & $\leq 20$ years & 44 & 80.00 & 11 & 20.00 & 0.93 & {$[0.81 ; 1.08]$} & 0.315 \\
\hline & $>20$ years & 138 & 85.71 & 23 & 14.29 & 1.00 & - & - \\
\hline \multirow{2}{*}{$\begin{array}{l}\text { Age of beginning } \\
\text { tobacco use }\end{array}$} & $>$ Median (16) & 82 & 83.67 & 16 & 16.33 & 0.99 & {$[0.88 ; 1.11]$} & 0.829 \\
\hline & $\leq$ Median (16) & 100 & 84.75 & 18 & 15.25 & 1.00 & - & - \\
\hline \multirow{2}{*}{$\begin{array}{l}\text { Cigarettes per } \\
\text { day }\end{array}$} & $>$ Median (20) & 92 & 97.87 & 2 & 2.13 & 1.33 & [1.19; 1.48] & $<0.001$ \\
\hline & $\leq$ Median (20) & 90 & 73.77 & 32 & 26.23 & 1.00 & - & - \\
\hline \multirow[t]{2}{*}{ Tobacco intake } & $\geq 20$ & 146 & 90.12 & 16 & 9.88 & 1.35 & {$[1.11 ; 1.64]$} & $<0.001$ \\
\hline & $<20$ & 36 & 66.67 & 18 & 33.33 & 1.00 & - & - \\
\hline \multirow{2}{*}{$\begin{array}{l}\text { Attempts to quit } \\
\text { smoking }\end{array}$} & None & 35 & 81.40 & 8 & 18.60 & 0.96 & {$[0.82 ; 1.12]$} & 0.564 \\
\hline & Some & 147 & 84.97 & 26 & 15.03 & 1.00 & - & - \\
\hline
\end{tabular}

$\mathrm{RP}_{\mathrm{b}}$ : Crude Prevalence Ratio; $\mathrm{Cl} 95 \%$ : confidence interval of $95 \%$; : level of significance considering the distribution of the chi-square test.

Table 3. Results of the bivariate analysis of the association between nicotine dependence and the instruments of psychological evaluation Cuiabá-MT, Brazil

\begin{tabular}{|c|c|c|c|c|c|c|c|c|}
\hline \multirow[t]{3}{*}{ Variables } & \multirow[t]{3}{*}{ Category } & \multicolumn{4}{|c|}{ Fagerström } & \multirow[t]{3}{*}{$\mathrm{RP}_{\mathrm{b}}$} & \multirow[t]{3}{*}{ CI 95\% } & \multirow[t]{3}{*}{$p$} \\
\hline & & \multicolumn{2}{|c|}{$\geq 5$} & \multicolumn{2}{|c|}{ Until 4} & & & \\
\hline & & $\mathrm{N}$ & $\%$ & $\mathrm{n}$ & $\%$ & & & \\
\hline \multirow[t]{2}{*}{ BAI } & $\begin{array}{c}\text { Moderate/ } \\
\text { severe }\end{array}$ & 72 & 82.76 & 15 & 17.24 & 0.97 & [0.86; 1.09] & 0.619 \\
\hline & Minimal/mild & 110 & 85.27 & 19 & 14.73 & 1.00 & & \\
\hline \multirow[t]{2}{*}{$\mathrm{BDI}$} & $\begin{array}{l}\text { Moderate/ } \\
\text { severe }\end{array}$ & 62 & 92.54 & 5 & 7.46 & 1.15 & {$[1.04 ; 1.28]$} & 0.025 \\
\hline & Minimal/mild & 120 & 80.54 & 29 & 19.46 & 1.00 & - & - \\
\hline
\end{tabular}

$\mathrm{RP}_{\mathrm{b}}$ : Crude Prevalence ratio; $\mathrm{Cl} 95 \%$ : confidence interval of $95 \%$; $\mathrm{p}$ : level of significance considering the distribution of the chi-square test.

Table 4. Adjusted Prevalence Ratio Poisson Crude Regression $\mathrm{RP}_{\mathrm{a}}$, of the variables associated with Fagerström $\geq 5$ (in 216 patients, with their respective interval of confidence (IC) of $95 \%$ and the p value of the variables selected by the backward method, Cuiabá-MT, Brazil

\begin{tabular}{|l|c|c|c|c|}
\hline Variables & Categories & $\mathrm{RP}_{\mathrm{a}}$ & Cl 95\% & P Value \\
\hline Sex & Male & 1.12 & $1.01-1.24$ & $\mathbf{0 . 0 2 9}$ \\
\hline & Female & 1.00 & & \\
\hline Cigarettes per day & $>$ Median (20) & 1.28 & $1.15-1.43$ & $<\mathbf{0 . 0 0 1}$ \\
\hline & $\leq$ Median (20) & 1.00 & & \\
\hline BDI & Moderate/severe & 1.12 & $1.01-1.23$ & $\mathbf{0 . 0 3 1}$ \\
\hline & Minimal/mild & 1.00 & & \\
\hline
\end{tabular}

$\mathrm{RP}_{\mathrm{a}}$ : prevalence ratio adjusted in the poisson regression model with selection of variables; $\mathrm{Cl}$ : confidence interval. 


\section{Discussion}

The results of this study demonstrate the influence of the relationship between smoking and depression. They show the association between the level of nicotine dependence, measured by the Fagerström test, and higher level of depression recorded by validated instrument to define the levels of depressive symptoms (BDI). These data are consistent with literature, where high level of addition by the Fagerström test was associated with severe depressive symptoms ${ }^{19,20}$.

It is known that the highest level of nicotine dependence is a determining factor for the success of smoking cessation and that several characteristics of the smokers are interrelated ${ }^{19}$. In this study, regarding the socio-demographic data, the male gender was the variable associated with high nicotine dependence, both for the bivariate analysis and the final regression model used. This result is consistent with some researches which show that being male was one of the variables considered as predictor of higher dependence, with men presenting higher dependence than women ${ }^{21}$. However, other studies show different results which report that the gender has not been associated with the level of dependence evaluated by the Fagerström test ${ }^{22}$.

A higher number of cigarettes smoked per day and high tobacco intake were also variables which were associated with high nicotine dependence. This result was expected, since there are numerous studies which show that the higher the daily consumption of cigarettes and tobacco intake, the higher is the nicotine dependence level ${ }^{19,21}$. The explanation for that is: people who smoke more than 20 cigarettes a day are usually nicotine-dependent and subject to strong withdrawal symptoms ${ }^{23}$. The nicotine-dependent smoker has a strong desire or sense of compulsion to consume the substance, difficulty in controlling the behavior of consuming the substance in terms of its initiation, ending or levels of consumption, a state of physiological withdrawal when the use of the substance has ceased or been reduced, which characterizes the withdrawal syndrome ${ }^{24}$.

In relation to the levels of depression and anxiety and the association with higher levels of nicotine dependence the results found here show that only depression can be associated, which confirms many of the literature reports ${ }^{19}$. On the other hand, these data differ from researches that find no association between nicotine dependence and depression in the male gender ${ }^{25}$, as well as non-association between severity of smoking and depression among male or female smokers ${ }^{22}$.

The depressive symptoms are heterogeneous and include sadness, anhedonia (inability to experience pleasure), problems of concentration, changes in appetite or weight, sleep disorder, excessive guilt and others ${ }^{24}$. The depressive symptomatology is higher in smokers with high level of addition, as well as those who have a history of higher cumulative consumption of cigarettes. Other reports show that tobacco is associated with psychiatric morbidity and moderate to severe depression ${ }^{19,26}$ and that nicotine seems to be a form of selfmedication, taking into account that it can change the mood and alleviate the depressive symptoms. In relation to this last hypothesis (self-medication), the authors report that smoking can fight the symptoms of discouragement and sadness which are typical of depression, however this fact leads the smoker to consume a higher quantity of cigarettes per day and that it can potentially increase nicotine dependence ${ }^{12}$. Moreover, smoking and depression can influence each other. Some smokers try to find relief from negative and undesirable feelings in the cigarettes and, thus, tobacco for these people can be a positive reinforcer ${ }^{27}$. The relationship between smoking and depression has not been investigated yet to determine the real meaning of cause-effect between tobacco and depression, as well as the adequate treatment ${ }^{9,28}$.

In this study anxiety has not been associated with the nicotine dependence level differing from the result found in other researches ${ }^{19}$. In relation to the association of nicotine with anxiety there is controversy, because some authors emphatically state that anxiety does not show a direct relationship with smoking. Others are categorical in emphasizing the relationship between them, pointing that it depends on the diagnosis of the type of anxiety disorder ${ }^{29}$. Anxiety can be defined as an emotional state with psychological and physi- ological components, which is part of the normal spectrum of human experiences and encourages performance. It can become pathological when it is disproportionate to the situation which triggers it, or when there is no specific object to relate to ${ }^{30}$. Yet, leaving this academic discussion, the role played by anxiety in the smokers in smoking cessation process must be remembered at the time of service, aiming to assist them to overcome their symptoms.

With regard to limitations of this study, one can highlight those related to the instruments of data collection. The Fagerström test, one of the most used questionnaires to investigate nicotine dependence, has its own limitations, since it can assess only physical but not psychological dependence ${ }^{5}$. The Beck Anxiety Inventory evaluates the presence of anxiety symptoms in general. However, it does not identify the presence of symptomatology of specific anxiety disorders, such as panic disorder and social phobia, among others. Even so, these minor limitations do not invalidate the results found in this study, because the data analyzed are important to support future planning actions to improve the assistance to smokers with depressive symptoms and high nicotine dependence. In conclusion, the high nicotine dependence is associated with male smokers, higher quantity of cigarettes smoked per day and the moderate/severe level of depression. It is suggested that instruments assessing levels of depression and anxiety are included within the smoking cessation programs, with the adoption of individual or group psychological interventions, giving special attention to smokers with depressive symptoms.

\section{References}

1. Gigliotti AP, Lemos T. Qual a relação entre o tabagismo e as comorbidades psiquiátricas? In: Araújo AJ. Manual de condutas e práticas em tabagismo. São Paulo: Sociedade Brasileira de Pneumologia e Tisiologia; 2012.

2. Reichert J, Araujo AJ, Gonçalves CMC, Godoy I, Chatkin JM, Sales MPU, et al. Diretrizes para a cessação do tabagismo - 2008. J Bras Pneumol. 2008;34(10):845-80.

3. Brasil. Ministério da Saúde. Instituto Nacional de Câncer (Inca). Abordagem e tratamento do fumante - Consenso 2001. Rio de Janeiro: Inca; 2001.

4. Santos VA, Migott AM, Bau CH, Chatkin JM. Tobacco smoking and depression: results of a cross-sectional study. Br J Psychiatry. 2010;197(5):413-6.

5. Halty LS, Hüttner MD, Oliveira Netto IC, Santos VA, Martins G. Análise da utilização do Questionário de Tolerância de Fagerström (QTF) como instrumento de medida da dependência nicotínica. J Bras Pneumol. 2002;28(4):180-6.

6. Mykletun A, Overland S, Aaro LE, Liabo HM, Stewart R. Smoking in relation to anxiety and depression: evidence from a large population survey: The HUNT study. Eur Psychiatry. 2008;23:77-84.

7. Batra A. Treatment of tobacco dependence. Dtsch Arztebl Int. 2011;108(33);555-64.

8. Mickens L, Greenberg J, Ameringer KJ, Brightman M, Sun P, Leventhal AM. Associations between depressive symptom dimensions and smoking dependence motives. Eval Health Prof. 2011;34(1):81-102.

9. Boden JM, Fergusson DM, Horwood LJ. Cigarette smoking and depression: tests of casual linkages using a longitudinal birth cohort. $\mathrm{Br} \mathrm{J}$ Psychiatry. 2010;196:440-6.

10. Patton GC, Carlin JB, Coffey C, Wolfe R, Hibbert M, Bowes G. Depression, anxiety, and smoking initiation: a prospective study over 3 years. Am J Public Health. 1998;88:1518-22.

11. Calheiros PRV, Oliveira MS, Wagner MF, Matos KS. Sintomas de ansiedade em tabagistas no início do tratamento. Rev Psicologia IMED. 2009;1(1):46-55.

12. Edwards AC, Kendler KS. Nicotine withdrawal-induced negative affect is a function of nicotine dependence and not liability to depression or anxiety. Nicotine Tob Res. 2011;13(8):677-85.

13. Piper ME, Cook JW, Schlam TR, Jorenby DE, Baker TB. Anxiety diagnoses in smokers seeking cessation treatment: relations with tobacco dependence, withdrawal, outcome and response to treatment. Addiction. 2010;106(2):418-27.

14. Castro MRP, Matsuo T, Nunes SOV. Características clínicas e qualidade de vida de fumantes em um centro de referência de abordagem e tratamento do tabagismo. J Bras Pneumol. 2010;36(1):67-74. 
15. Fagerström O. Treatment of nicotine dependence. Prog Brain Res.1989;79:321-6.

16. Beck AT, Epstein N, Brown G, Steer RA, Steer RA. An inventory for measuring clinical anxiety: psychometric properties. J Consult Clin Psychol. 1988;56:893-7.

17. Beck AT, Ward CH, Mendelson M, Mock J, Erbaugh J. An inventory for measuring depression. Arch Gen Psychiatry. 1961;4:561-71.

18. Barros AJD, Hirakata V. Alternatives for logistic regression in cross-sectional studies: an empirical comparison of models that directly estimate the prevalence ratio. BMC Med Res Methodol. 2003;3(21):1-13.

19. Urdapilleta-Herrera EC, Sansores RH, Ramíres-Venegas A, Méndez-Guerra M, Lara-Rivas AG, Guzmán-Barragán SA, et al. Ansiedad y depression en fumadores mexicanos y su relación con el grado de adicción. Salud Publica Méx. 2010;2(51):120-7.

20. Fagerström K, Furgerg H. A comparison of the Fagerström Test for Nicotine Dependence and smoking prevalence across countries. Addiction. 2008; 103:841-5.

21. Afonso F, Pereira MG. Preditores da dependência nicotínica e do comportamento planeado para deixar de fumar. Aná Psicológica. 2013;31(1):17-22.

22. Castro MGT, Oliveira MS, Araujo RB, Pedroso RS. Relação entre gênero e sintomas depressivos e ansiosos em tabagistas. Rev Psiquiatr Rio Gd Sul. 2008;30(1):25-30.
23. Rosemberg J. Nicotina: droga universal. São Paulo: Secretaria de Estado da Saúde - SES/CVE; 2003.

24. American Psychiatric Association (APA). Diagnostic and Statistical of Mental Disorders 4 - DSM-IV. Practice guidelines for the treatment of psychiatric disorders. Estados Unidos; 2006.

25. Alati R, Kinner S, Najman JM, Fowler G, Watt K, Green D. Gender differences in the relationships between alcohol, tobacco and mental health in patients attending an emergency department. Alcohol. 2004;39(5):463-9.

26. Bortoluzzi MC, Kehring RT, Loguercio AD, Traebert JL. Prevalência e perfil dos usuários de tabaco de população adulta em cidade do Sul do Brasil (Joaçaba, SC). Ciênc Saúde Coletiva. 2011;16(3):1953-9.

27. Rondina RC, Gorayeb R, Botelho C. Relação entre tabagismo e transtornos psiquiátricos. Rev Psiq Clín. 2003;30(6):221-8.

28. Weinberger AH, Mazure CM, Alejandra-Morllett BA, Mckee SA. Two decades of smoking cessation treatment research on smokers with depression: 1990-2010. Nicotine Tob Res. 2013;15(6):1014-31.

29. Hofman SG, Richey JA, Kashdan TB, McKnight PE. Anxiety disorders moderate the association between externalizing problems and substance use disorders: Data from the National Comorbidity Survey-Revised. J Anxiety Disord. 2009;23:529-34.

30. Andrade LHSG, Gorestein C. Aspectos gerais das escalas de avaliação de ansiedade. Rev Psiq Clín. 1998;25(6):285-90. 